\title{
Cardiac MRI findings in patients with Myocarditis
}

\author{
Darach O h-lci, Yves Louvard, Thierry Unterseeh, Thomas Hovasse, Marie Claude Morice, Jérôme Garot \\ From 2011 SCMR/Euro CMR Joint Scientific Sessions \\ Nice, France. 3-6 February 2011
}

\section{Background}

Cardiac Magnetic Resonance Imaging (CMR) is a . The recent conjoint report of the American College of Cardiology and the SCMR has classified its use as "appropriate" or "Class A Indication" in inflammatory cardiomyopathy. The aim of this study was to describe the typical findings in patients diagnosed with myocarditis undergoing CMR.

\section{Methods}

Patients who underwent CMR at ICPS who were diagnosed with myocarditis on the basis of cardiac imaging and clinical findings (patients, $\mathrm{n}=187$ ) between November 2009 and September 2010 were identified through the use of the cardiology database. All patients underwent a similar protocol to look for:

1. LV and RV function

2. The presence of pleural effusion

2. Tissue edema, as seen by an elevated $\mathrm{T} 2$ signal

3. Myocardial necrosis or scarring, as indicated by the presence of late gadolinium enhancement (LGE)

\section{Results}

Most patients ( $\mathrm{n}=175,93.6 \%)$ had LGE in a pattern sparing the subendocardium. Areas of hypokinesis were common ( $\mathrm{n}=62,33.2 \%)$, as was the presence of myocardial edema $(n=58,31.0 \%)$. Pericardial effusions were less common $(n=35,18.7 \%)$. Of those patients who also underwent stress perfusion CMR, none showed evidence of ischemia. Left Ventricular ejection fractions were largely preserved $(57.3 \% \pm 10.4 \%)$ and end-diastolic volumes normal $\left(69.2 \pm 21.4 \mathrm{ml} / \mathrm{m}^{2}\right)$.

\section{Conclusion}

CMR abnormalities are common in patients with myocarditis. A typical pattern of delayed enhancement is by

Institut Cardiovasculaire Paris Sud, Massy, France far the commonest abnormal finding in this group of patients. The use of a combination of CMR findings in keeping with the clinical picture is necessary for accurate diagnosis.

Published: 2 February 2011
Submit your next manuscript to BioMed Central and take full advantage of:

- Convenient online submission

- Thorough peer review

- No space constraints or color figure charges

- Immediate publication on acceptance

- Inclusion in PubMed, CAS, Scopus and Google Scholar

- Research which is freely available for redistribution
() Biomed Central

\section{() Biomed Central}

(c) 2011 h-lci et al; licensee BioMed Central Ltd. This is an open access article distributed under the terms of the Creative Commons Attribution License (http://creativecommons.org/licenses/by/2.0), which permits unrestricted use, distribution, and reproduction in any medium, provided the original work is properly cited. 